\title{
Origins and Social Functions of Bagpipe Traditions among the Finno-Ugrian Peoples*
}

(2012)

\author{
Ain Haas \\ Indiana University at Indianapolis \\ ahaas@iupui.edu
}

The origins and relationships of the Finno-Ugrian peoples can be clarified in a variety of ways, involving comparative analyses of their languages, genes, folk tales, symbolism, cosmology, etc. This paper examines one aspect of their musical heritage, bagpipe traditions, which seemed to be in danger of decline until recently. The focus is on three nationalities--Estonians, Mari, and Hungarians--whose bagpipe traditions have been particularly well documented. Their enthusiasm for revitalizing this element of their ethnic heritage also seems quite strong.

The analysis considers the etymology of bagpipe names, the design and construction of the instrument, the rites and performance contexts associated with it, and the processes by which the traditions were salvaged and revitalized. Such points will clarify how these peoples obtained bagpipes, integrated them into their cultures, and adapted to the forces of modernization and globalization.

\section{The Estonian Bagpipe (torupill)}

The Estonians are the only Finnic group in the Baltic Sea area among whom the bagpipe traditionally had great popularity (Tõnurist 1977: 212). It was played in all parts of the country (Rannap 1972: 28-29). It was also popular among the Swedes who settled in Estonia's coastal areas and islands in medieval times (Nyberg 1990).

The most common Estonian word for bagpipe is torupill 'pipe instrument'. Both parts of this compound word, toru 'pipe, tube' and pill 'music instrument', may have Finnic roots. Cognate words occur in other languages of Baltic Finns (Metsmägi et al. 2012: 542, 370). It also seems plausible that toru could be derived from Latvian

\footnotetext{
${ }^{*}$ The author thanks Erik Juzykain (Ministry of Culture, Mari El, Russia) and Ferenc Tobak (Tobak Studios, Fort Bragg, California, USA) for providing a wealth of information about Mari and Hungarian bagpipes, respectively.
} 
taure 'horn', a tubular instrument blown to make signal sounds, and thus related to taurs and Estonian tarvas 'aurochs' (Lithuanian taūras, Russian tur, akin to Latin taurus and Spanish toro 'bull'), for the extinct long-horned wild cattle of Europe. The word toru has further been linked to torin 'growl, muttering' by Faehlmann (1848: 684), who also follows Arndt (1747: 166) in suggesting a link to the thunder deity Tooru or Taara (like Scandinavian Thor).

Arndt also notes that the Estonians on Saaremaa Island believed that a god (forest spirit?) was in the bass pipe of a bagpipe, for it was made of something that had grown in the woods. Likewise, the amount of howling done by a dog being hung so that its skin could be used for a bagpipe was considered a foretoken of the sound quality of the instrument (Tõnurist 1976: 48-49). Both cases suggest that the spirit of the living thing used to make a bagpipe somehow lives on in the finished instrument, which is congruent with the animist Estonian folk religion.

Instead of coming from a Finnic root, the second element -pill 'music instrument' may be derived from Swedish spel, Latvian spēle, or German Spiel. These all mean 'playing'. Estonians' aversion to multiple consonants at the beginning of a word would account for the dropping of the 's'. The Finnish ethnomusicologist Timo Leisiö (2014) points out that the long initial vowel sound of such an IndoEuropean word differs from the short sound in Estonian/Finnish pill(i). He suggests that the latter may instead be derived from Low German or Danish spille 'spill [slender piece of wood], spool, cylinder'. Such a term seems quite appropriate for the pipes stuck into a bag, and Baltic Germans did apply a cognate word for both a spool (of yarn) and a reed pipe. (See also Leisiö and Tainio 1988: 4 and Allmo 1990: 286-287.)

Rarer names for the Estonian bagpipe include kotipill 'bag instrument', lõotspill 'bellows instrument' (also used for accordion), kitsepill 'goat instrument', and simply pill 'instrument' (Tampere 1975: 19; Tõnurist 1976: 47; 1998: 465). The term põispill 'bladder instrument' has not been reported for the bagpipe, although the bag might be from a pig's or cow's bladder (Tõnurist 1976: 48).

The bagpipe was called rakkopilli 'bladder instrument' among Votes, Izhorians, and Finns of Ingria (east of Estonia), but it disappeared in the late 1800s (Tõnurist 1977). It was also called that in Finland, as well as säkkipilli (evidently derived from the Swedish säckpipa 'sack-pipe'), and was more commonly played in Swedishspeaking areas. The same name was also used for other blown but bagless instruments (e.g., bark or leaf whistles), so the few mentions in Finnish folklore are not clear evidence of bagpipe usage (Allmo 1990: 283-290, citing Timo Leisiö). Finnish church paintings showing bagpipes may not reflect local traditions, since the artists may have come from elsewhere or copied motifs from other places (Allmo 1990: 56, 285, 362). Another complication is that immigrants with imported instruments may be behind some travellers' reports of local traditions. 
The Livs of Latvia had their own Finnic-language compound term for the bagpipe, ilgõma'g 'seal stomach' (= hülge magu in Estonian) (Viitso \& Ernštreits 2013: 72). Estonians also preferred seal stomachs for making the bag. Their Latvian neighbors used other animals' skins or bladders instead (Priedīte 1988: 32-35).

There is no confirmation of any pattern of bagpipe use among Karelians, Vepsians, or Saami. A contemporary Karelian folk music ensemble (Myllärit) in Petrozavodsk, Russia has a bagpipe player, but his instrument is from Estonia.

If Estonians got their bagpipe from any kindred people, one would expect adoption of a cognate word for it. The one piece of evidence clearly linking Finnish and Estonian bagpipes points to diffusion in the other direction. A recollection of bagpiping in the late 1700s in Finland's Lampi district involves an estate where the owners and workforce came during the previous century from Saaremaa, an Estonian island with well-documented bagpipe traditions (Leisiö and Tainio 1988: 9; Allmo 1990: 288). Leisiö's etymological analysis (2014) suggests that the Finnish word pilli 'pipe' was derived from the Estonian pill around the year 1300.

In contrast to other Baltic Finns, Estonians' bagpipes were more elaborate and varied in design, had an important part in community activities (as discussed below), and influenced other instrument traditions. Estonia's violin and accordion players performed melodies recalled as coming from bagpipers, and even played them with a drone style of accompaniment (Tõnurist 1976: 52; 1998: 465; Nyberg 1990: 281). It is hard to see such centrality of the bagpipe in Estonia as inspired by an instrument with marginal status among kindred peoples. It is also unlikely that Estonians invented their bagpipe without inspiration from any of the nearby Indo-European peoples with similar instruments, who had taught them agriculture, animal husbandry, metallurgy, and other arts.

The etymology of torupill is inconclusive with regard to which neighbors were the likeliest source of the instrument. Swedes called the instrument säckpipa 'sackpipe' (like German Sackpfeife), but Swedish settlers in coastal Estonia often used drommpip 'drone-pipe', which refers to the constant bass tone(s) that accompany the melody (Nyberg 1990: 245). Germans also called it Dudelsack, apparently due to the sound (like the English word tootle) from a repetitive blowing of an instrument.

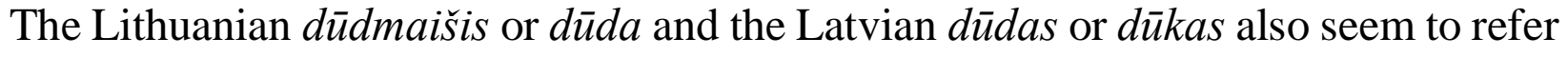
to the sound. Priedīte links the latter name to the phrase dīcoša skanna 'buzzing sound'. The Russian name volynka refers to a border area (Volynia), where the territories of Russia, Byelorussia, Poland, and Ukraine meet (Baines 1960: 79-80; Tampere 1975: 19). The Russians nearest Estonia did not have bagpipes (Tõnurist 1976: 48), and there is generally little evidence of bagpipe traditions among Russians, in contrast to many other nationalities of the Russian or Soviet domain (Allmo 1990: 294-5). None of these terms of nearby Indo-Europeans match torupill exactly, but the Swedish and German concept of 'sack-pipe' comes closest to the Estonian term 
'pipe instrument'.

Another hint of a Swedish origin is the identical design and construction of Estonian and Swedish-Estonian bagpipes (Nyberg 1990). In his comparative analysis, Baines (1960: 69-71, 90-92, 103) assigns Estonian bagpipes to the "Baltic" type, along with Latvian and Swedish ones. The "Baltic" bagpipes all share a singlereed design and cylindrical chanters, and often have a cylindrical resonating chamber at the drone's end. Rüütel (1969) finds evidence of a link to Sweden in the texts and melodies of a genre of dance songs played on bagpipe, but Tampere (1999: 11) notes that an older genre of non-dancing folk tunes includes bagpipe melodies, predating the diffusion of Swedish-influenced dance tunes.

The basic form of a traditional Estonian bagpipe (Figure 1) is an animal's stomach sack, usually from a seal but sometimes from a cow, moose, or dog. Some of the intestine and esophagus is retained, making a distinctively long appendage for the downward-hanging drone pipe and a shorter one for the chanter or melody pipe. The bag could also be made from the bladder of a pig or cow, or the hide of an animal (goat, dog, cat, seal, lynx, raccoon dog, etc.) with the fur on the outside.

The mouthpiece or blow-pipe is attached to the bag via a wooden stock, and typically has a flexible leather flap serving as a valve. This allows air to enter the bag but not to escape from the same hole. It also guards against the player's contracting a respiratory infection (known as "pipers' lung" among Scottish pipers) through inhalation of moldy air from inside the bag.

The melody pipe or chanter has a basically cylindrical shape, with seven holes (including a high thumbhole), allowing for eight notes of a diatonic scale. Looking at transcriptions of old bagpipe tunes, the range typically includes the first six notes of the diatonic scale, plus the seventh note just below the key (tonic) note. There is considerable variation beyond that. In some cases, the range includes the the low dominant note below the key note; in other cases, it includes the high seventh or high octave note. The instruments made more recently by Ants Taul tend to be in the key of $\mathrm{G}$; the notes begin with low $\mathrm{D}$ when all the holes are covered, and then go up (without E) to F\# G A B C D E. The holes' edges might be scalloped, to make a more comfortable depression for fingers to press against. Wax might partially cover a hole, for tuning adjustment. An oblique hole or two might be drilled at the bottom of the chanter, for inserting straw or twigs for the purpose of tuning (Tõnurist 1976: 49). Such materials may also be put into the bottom of the tube, to prevent overtones detracting from the sound (Söderbäck,1940: 210). To make the reed, a section from the stem of a water reed or goose quill could be slit so that a flap could vibrate when air was forced out of the bag. A piece of reed tied to a hollowed rod (analogous to a clarinet's mouthpiece) is preferred nowadays. The reed was inserted into the bag through the hole in a wooden stock.

Most bagpipes have one long drone pipe, often in two segments, with a joint 
enabling adjustments in length for tuning. A hollow resonating chamber of wood (not horn) was appended at the bottom. Two-drone instruments are also fairly common. The pipes are lacquered, sometimes stained, and often decorated with bands, bulges, or grooves created by lathe work. Drones are tuned to either an octave below the key note of the melody, or to the fifth (dominant) note below it.

Baines (1960: 90) calls bagpipes such as the type in Estonia "starkly primitive", without explaining the characterization. Such a label might be more appropriately applied to the Votic-Izhorian-Ingrian instrument, which was droneless (like medieval European bagpipes), had a small bag made from a bladder, a simple chanter made of a reed or willow-bark, and only five fingerholes (including a thumbhole). A similar simple design has also been reported for Poland (Tõnurist 1977: 213). This might have been the original form of Estonian bagpipe, before a more advanced form arrived via the medieval Hanseatic League, the trading network that brought merchants and wares to Estonian towns from places like Sweden and Germany.

Drawings and photos from the mid-17th to the early 20th centuries (Pulst 1973; Tampere 1975; Nyberg 1990) show that the instrument was usually held in front of the player, with the bag against the chest, but sometimes under the arm. The player might stand or sit. Drone pipes are usually suspended below the wrist or elbow with a loop of ribbon or twine, thereby kept from dangling straight down, which could impede the player's walking or muffle the sound.

Both closed and open fingering systems were used, judging from old photos. The closed method involves covering most of the holes most of the time, and lifting isolated fingers, to obtain various notes. This makes an interesting bubbly or sparkly sound. The open method involves sequential lifting of fingers, with no covering of lower holes when middle holes are open. It yields cleaner notes.

The route by which bagpipes arrived in Estonia is unknown, but their diffusion in Northern Europe was evidently promoted by the Romans and/or Vikings, who could have acquired it during their visits to the Near East (Allmo 1990: 45). Bagpipes were rarely mentioned or depicted in European historical sources until the late 13th century (Baines 1960: 67). The earliest mention of bagpipes in a historical document from Estonia is at the end of the 1300s, in a German-dominated town setting (Nyberg 1990: 242). By the mid-1500s, the instrument had become well-rooted in the countryside (Tõnurist: 1976: 47), alongside the older national instrument, the Baltic psaltery (kannel).

In 1584, Russow wrote that large bagpipes were plentiful in every village, used for entertainment, as well as bonfire rites blending Christian and pagan elements (Russow 1967: 87-88, 228). Peasants brought wax figures of farm animals to the church altar as a way to seek protection against diseases that could harm their creatures, and afterward they celebrated with drinking, singing, dancing, and orgiastic disorder to the accompaniment of bagpiping. Beginning in 1680, there are 
reports of bagpipers accompanying the wintertime procession of the "metsik cult". This involved transporting a clothed straw figure of a man or woman to remove threats to crops, herds, and fishing of the local community (Västrik 1998; Tampere 1975: 22). Bagpipers also served as heralds on horseback-- announcing the arrival of a "king" during a peasant uprising in 1560 (Tõnurist, 1976: 49, citing Johannes Renner, 1556-61) or leading a wedding procession in the 1630s (Olearius 1998: 121). They also led archaic ritualistic line dances, and accompanied processions of Martinmas mummers and Christmas carolers (Tõnurist 1976: 50). Estate owners hired pipers to create a festive atmosphere for harvest work. Making funny squeals, players tailed laggard workers to draw attention to lack of effort and to motivate the latter to keep up with other workers (Tampere 1975: 22; Tõnurist 1976: 50). On the other hand, bagpipes were associated with licentiousness, through their role in festivities at taverns and in celebrations and processions with pagan undertones, which explains why pipers ran into criticism and even persecution from religious authorities.

By the beginning of the 20th century, bagpipes had been replaced by violins and accordions. Changing musical tastes help account for this shift. Bagpipes are inherently unsuitable for modern and foreign compositions that use a wide range of notes, a chromatic scale, key changes, or other embellishments not needed for traditional folk music. Bagpipes are also less suitable for ensemble playing, since the tuning drifts as the reeds get moist. Modern audiences like diversity of instrumentation, harmonies, countermelodies, volume changes, and other features that are hard to provide with bagpipes. Urbanization may also have been a factor, since practicing the instrument is problematic in dense housing situations. Traditional players usually made their own instruments, but townsfolk would have difficulty obtaining seal stomachs, turning lathes, etc. When standardized instruments of other types became available and affordable, bagpipes declined in popularity.

Although traditional players were still active and esteemed in the 1920s and some made audio recordings in the 1930s (Pulst 1973; Kiviberg 1994), there was little demand for their services at weddings or other functions in the mid-20th century. Their detailed knowledge of bagpipes died with them. The last player to learn in a traditional setting (Aleksander Maaker, the nephew of Estonia's most famous piper, Juhan Maaker) died in 1968, but he did pass on some knowledge of instrument-making and playing to Olev Roomet, a professional musician in Tallinn. For the 1970 song festival in Tallinn, Roomet enlisted an instructor of instrumentmaking to help make some 25 copies of a museum specimen, which proved rather unreliable for concert performances but were good enough for demonstrations and recordings that inspired other urbanites to take up the instrument. Among them was Ain Sarv, who became the bagpipe player of the folk music ensemble Leegajus and 
an instructor of folk music at Viljandi Culture College, later called Viljandi Academy and affiliated with Tartu University (Kiviberg 1994).

Another leader of the bagpipe revival is Ants Taul, a farmer in Riidaja and the main producer of bagpipes in Estonia. He learned to play on an old chanter, and figured out how to make a suitable bag, reed, and other parts on his own. After a short stint with the Leegajus ensemble, he formed the Torupill ensemble, made several recordings, became an instructor of bagpipe playing at the Viljandi Academy, and built a lodge for hosting visitors at his Bagpipe Farm. He made almost all of the bagpipes being played in Estonia today, experimenting with new materials and features in response to customer requests, practical needs, and his own curiosity. He devised ways to adjust the tuning of a drone reed without dismantling the instrument, change the drone note for quick shifts between major- and minor-key playing, obtain half-notes for chromatic playing, etc. Despite these innovations, his instruments have a traditional look. Among those who studied with him and/or got instruments from him are several female musicians (Celia Roose, Sandra Sillamaa, Cätlin Jaago Mägi) who are prominent teachers or researchers of folk music. (Only males appear in the old photos.) Male disciples include Juhan Suits (current bagpipe instructor at Viljandi), Lauri Õnapuu (player of folk instruments in the heavy metal band Metsatöll), Ando Kiviberg (organizer of the Viljandi Folk Festival and director of the Traditional Music Center in Viljandi), and Ants Taul's son Andrus Taul (bagpipe maker). His instruments are also being used by Estonians and Estophiles outside Estonia, with information about playing techniques and instrument care being made available via videos and the Internet.

\section{The Mari Bagpipe (šüvyr)}

The Mari or Cheremis of the Volga Finnic group in Russia have an instrument with a bag made from the bladder of a bull, pig, or sheep. The pipes are inserted into the bag directly, not held in stocks. Mari instruments show the same kinds of repairs done on Estonian ones. A round plug (of wood?) was put into the bag, and twine was wound around it on the outside of the bag. (See photo in Nettl 1960: 60)

Bags made of internal organs (bladders or stomachs) are quite unusual in the world of bagpipes (Szabó 2004: 44). The Mari bagpipe (Figure 2) resembles the simple bladder instrument of Ingria. Yet the Mari chanter (Figure 3a) has two parallel pipes, both with fingerholes. The pipe on the player's right (viewer's left) is for melody, and has four holes and sometimes two or more uncovered resonance or timbre holes, off to the right side. The other pipe is for contrabass harmony or countermelody, and has two holes. The player uses three fingers of one hand (index, 
middle, and ring fingers) to play the upper notes on the melody pipe. Some players use the right hand for this; others the left. The other hand plays the lower notes, but its index or pointer finger covers both the top hole of the contrabass pipe and the lowest hole on the melody pipe simultaneously (Figure 4). As the two pipes play in and out of unison, a staccato-like effect is heard for the bass part, instead of a constant drone.

Until a century or so ago, these pipes were made of the shinbones of a water bird (swan, goose, stork, crane), with oval holes. They are now made of metal (tin, copper, aluminum), with the holes drilled round. The tubes are embedded into a hollowed wooden yoke or trough. Most of the yoke's front side is cut away to allow access to the holes. The back side is cut away near the reeds, to facilitate tuning. The yoke prevents abrasion on the delicate bag (Baines 1960: 49), but a more important function is to hold the two pipes in a stable position in relation to each other, to enable one finger to cover holes on the two pipes simultaneously.

Two tubular reeds, each with a partially separated sliver that vibrates with the passage of air, lead into the double-chanter's tubes. A ball of wax on each reed can be pushed up or down for tuning. Modern instruments may have reeds of metal or celluloid, which gives them a louder and hasher sound (Allmo 1990: 296-297).

At the bottom of the double-chanter, the two pipes enter a common bell. This could be made from a cow's horn or carved from wood (Allmo 1990: 296). Its edge was not serrated, in contrast to most other bagpipes in the southeast European group that includes the Mari shüvyr (Baines 1960: 43-51).

The mouthpiece is made of hollow bone or wood. There is no valve or flapper to stop the air from escaping when the player takes a breath (Baines 1960: 49). It thus takes a lot of lungpower to keep the bag inflated. The player either presses the instrument against the chest or extends it in midair away from the body, sometimes even at shoulder height (Gerasimov 1996: 28, 154-167).

There is evidently no standard tuning set-up. On the basis of various transcriptions of šüvyr tunes (by the author and in sources such as Nettl 1960: 72), the notes of the contrabass pipe are something like $\mathrm{G} \mathrm{B} \mathrm{C}$ and the notes of the melody pipe are something like G B C D E. However, the B is sometimes more like Bb and the $\mathrm{E}$ is sometimes more like Eb. Nikiforov (1959: 52-53) indicates that some regions prefer the former and some the latter type of set-up, but presents them as being in the key of $\mathrm{C}$. It is possible that the regional variation may depend on whether instrument makers emphasize appearance (e.g., fairly even spacing of holes) over aural precision. There are occasional bagpipe duets, if two players have instruments made by the same craftsman; otherwise, it is too hard to get them to be in tune with each other.

The name š̈̈vyr may simply be derived from š̈̈vyron, which Nikiforov (1959: $48,51)$ indicates as meaning 'bladder'. Yet the word šüvyr is reminiscent of the 
Persian shaifur and Hebrew shofar, a bugle-type wind instrument made from a ram's horn. The latter two have no fingerholes or bag, but the general shape of the Mari chanter assembly (pipes, yoke, bell) is similar. Morphologically, the Middle Volga bagpipe of the Mari and their neighbors is most like the bagpipes of the Caucasus Mountains, Cyclades Islands of Greece, and Malta. All of these have a doublechanter, enclosed in a yoke, with a common bell for the two tubes. This suggests that the ancient Greek trade network may have been involved in the transport of this instrument type to the Middle Volga region, but likely intermediaries use other names for the bagpipe (Greek tsambouna 'symphony?' or aski 'bag', Turkish tulum 'bag', Georgian stviri, Armenian parakapzuk, Persian ney anban). The Mari term is similar to the Chuvash word shapar, used by their Turkic neighbors for their own bladder bagpipe with a double-chanter (Baines 1960: 43-48). Considering that Mari singing styles diverge from those of most other Finno-Ugric groups and have much in common with those of the Chuvash and some other Turkic peoples (Nettl 1960: x, 85-87), a similar source for Mari bagpipes seems eminently plausible.

The kindred Mordvins have a similar bagpipe, but call it puvama, perhaps related to puva 'to blow'. Alternative names ufam and fam seem like contractions thereof, but not palama. A diagram of fingering positions and a transcription of a tune played on the Mordvin bagpipe appear in Väisänen (1948; also Baines 1960: 50). The bass pipe has three holes, and makes the notes D E F\# G. The melody pipe has six holes, for D E F\# G A B C?. A closed system of fingering was used, whereby most of the holes are covered and one to three fingers are lifted as needed. The contrabass pipe matches the lower part of the melody pipe (Figure 3c). The corresponding holes are always covered or open simultaneously on the two pipes, by fingers stretching across both pipes.

Among the Mountain Mari, in the foothills of the Urals, female players are common. Not so among the Meadow Mari near the Volga River. Only male players can be seen in the photos in Gerasimov (1996), which show both traditional contexts and modern stage performances. No female players can be seen in the television coverage of the Shüvyr Festival of 2009. (See the Web site at http://www.youtube.com/watch?v=7ZdCEuG6y6A.)

The Mari bagpipe is usually played to the accompaniment of singing and drumming. Both the bagpipe and drum may be decorated with a diamond shape called ke-che. This symbol of the sun is the most common decorative element in Mari folk art. These instruments are typically played after a church wedding ceremony, when the new couple arrives at their home. The musicians make a vibrating sound, as the groom's parents come forward to greet the couple. The bagpipe is also played at funerals and to welcome visitors.

The bagpipe and the lap-harp kusle are the two folk instruments associated with prayers and cult-rituals (Gerasimov 1996: 187). When planting of crops is finished, 
a bagpipe player circles the fields, along with a drummer and singers, to ensure a good harvest. The Mari are predominantly Russian Orthodox Christians today, but some pagan customs such as this fertility rite survive. Another ritual connected with bagpipe music is the wintertime Feast of the Sheep's Foot (Baines, 1960: 49). This was an occasion for merrymaking and masquerading. Young people sought information about the hair color, size, and age of their future spouses by examining the characteristics of the sheep they grabbed in a dark pen. It also involved tossing hemp seeds into the pen to ensure a good crop of this plant, and pulling sheep's legs to promote the birth of twin lambs (Sebeok and Ingemann 1956). There are hints that the Mari once used bagpipes for war dances. Pipers recruited into the army took their instruments with them.

Among the Mordvins, the bagpipe had an important ritual function in the animistic cult of trees. Boyarkin reports that for public calendar prayers at a sacred grove, special bagpipes (with archaic designs, bags made from the bladders of sacrificed bulls, and horn bells from these animals) were played by musicians hoisted above the crowd. The pipers, along with players of the nyudi 'double-cane clarinet' and torama 'horn trumpet' and the prayer leaders, served as intermediaries between the singing people and their patron deities. The same types of musicians also played during a girls' rite of the icebreaking period, when the water deity Vedyava was implored to curb the "liberated powers of nature amassed in winter." Such puvama-nyudi-torama ensembles also played during prayer-songs for another ritual associated with the water goddess cult--following the first wedding night, when the bride visited a natural water reservoir or well. This was a fertility rite, as young people (but not old ones) were encouraged to dance on these occasions and engaged in "considerable licentiousness" (Boyarkin 1995). Whether this was done to ensure good fishing, adequate rainfall, a healthy water supply, fertility (of fields, animals, or people), or some other kind of good fortune is unclear.

Bagpipe making among the Mari is no longer done by village-based traditionalists. Instead, the craft is now in the hands of folklore enthusiasts affiliated with cultural centers in towns. A bagpipe maker of the late 20th century was Pëtr Echeikin, director of a Mari cultural center and leader of a folk music ensemble. A currently active successor is Sergei Danilov, an actor with the Mari State Drama Theater. The Ministry of Culture of the Mari El Republic buys his instruments, to distribute to groups of folk musicians. Such recently made instruments were on display at the Mari Bagpipe Festival "Shüvyr" of 2009, which also featured pipers such as Evgenii Kamenshchikov of the Murseskem ensemble and folk music instructor Sergei Pchëlkin. Future Mari bagpipe makers can use the drawings and instructions in the books of Nikiforov (1959: 48-53) and Gerasimov (1996: 142-151). 


\section{The Hungarian Bagpipe (duda)}

The bagpipes of Hungary are made from the hide of a sheep or other animal (goat, dog, antelope, calf, colt), cured with alum and salt, usually turned inside out, sometimes depilated. Leaving a hairy inner lining prevents moisture from dissolving the salt in the pores, which would make for a leakier bag. Two legs and neck (or tail) provide natural openings for the wooden stocks that hold the pipes. The large opening where the rest of the hide was cut off is closed by twisting and tying, or by lacing (Szabó 2004: 44-48).

The blowpipe has a leather flap for a valve. Bellows are sometimes used instead, to prevent the damage that the moist exhaled air could cause. Bellows also solve the problems of "piper's lung" disease and moist reeds going out of tune, and facilitate the player's singing while piping. There are valves for both the air intake and outflow openings of the bellows. Leather straps secure the bellows to the side of the musician's body as well as to the arm operating the bellows. Even when a blowpipe is used, the bag is squeezed under the arm rather than against the chest.

The stock holding the chanter is typically carved like the head of a ram or goat, less often another animal or human. The cylindrical hardwood double-chanter is held in the creature's mouth, creating the impression that the animal blows the instrument (Figure 5). The double-chanter's melody tube (Figure 3d), which could be either on the player's left or right, typically has five holes, plus a long vent hole for the tonic or key note on the side. A small fleahole at the top of the melody tube raises the pitch of any note by a semitone when left uncovered, enabling a vibrato-like trilling effect. The contrabass tube has one hole at the bottom. Covering and opening it yields a pulsating, staccato-like variation in the drone sound, between the keynote and the lower fifth (dominant) note. There is no simultaneous covering of holes on the two tubes by the same finger, as in the Mari playing style. Some instruments have a backside hole for the high 7 th or octave note. When interspersed with other notes, this makes a distinctive hiccupping, squeaking sound.

Sometimes the chanter assembly has an extra tube or two, for constant droning. This enables simultaneous playing of the melody, keynote, dominant, and octave tone. The triple or quadruple pipes can be held together in a yoke, instead of being tied or joined via metal hoops like double chanters usually are. The extra bores can be obtained by drilling into the yoke, instead of assembling more tubes.

At the bottom of the contrabass tube, a "foot" or extension of wood, brass, or horn is attached to lengthen the tube somewhat. This is often in the shape of a horse's head. It is secured to the chanter with a chain, which could also hold a pointed implement, for adjusting the tuning wax in the fingerholes.

The separate, single bass drone is a long tube, usually of three to four wooden 
sections, adjustable at the joints. Sometimes there is just one piece of brass tubing instead. The bass pipe usually hangs down from the bag, but sometimes rises upward and rests on a shoulder. In rare cases it is convoluted, like the tube on a brass instrument. It has a horn (or wooden or brass bell) at the end, usually unserrated and turned upward by a V-shaped wooden joint that connects it with the long tube. The same kind of upturned horn may also be found at the bottom of the contrabass tube of the double-chanter, in lieu of the horsehead extension.

The single reed for each tube could be made from a slotted piece of cane, sliver of wood, or quill. The bass pipe's reed is much larger than the chanter's reeds, permitting a drone sound one or two octaves below the keynote of the chanter. Some instruments require closed fingering, the preferred style of playing. The tuning is usually in the key of $\mathrm{G}$ or near it. It is often imprecise, which explains the rarity of joint playing. The melody chanter begins with the keynote at the low end, and can make all the notes of the major scale up to the octave above. Skilled players can get half-tones or chromatics by partially covering holes and varying the pressure on the bag (Manga 1965: 34, 37, 38, 51, 70, 83, 91-92).

The pipes are richly decorated with grooves, inlays, carvings, paint, and other adornments, with many regional variations. There are only a few examples of handcarved pipes. Usually they are lathe-turned (Szabó 2004: 44-47, 49, 51-53, 79-131; Baines 1960: 77-79). The elaborate decoration and sophisticated design of the Hungarian bagpipes stand out in comparisons to the Estonian and Mari types, and are especially noteworthy when considering the humble social status of the shepherds and swineherds who made and played such instruments.

Éri (2001) notes that $d u d a$ became the main word for bagpipe in the Hungarian literary language only in the 20th century. It has been in use at least since the 11th century, coexisting with two-dozen other words for bagpipes, including the Slavic gajd. Most of the alternative terms contain sip 'pipe, fife, whistle'. (See also Manga 1965: 11-15.) There could be a connection between $d u d a$ and German Dudelsack (discussed above in connection with Latvian and Lithuanian names) or to Turkish düdük 'pipe' (Baines 1960: 74). Some Slavic groups (Czechs, Poles, Ukrainians) also use $d u d a$, among other terms.

The instrument is called gajda or some variant thereof among most of the nearby Slavic-language groups (Serbs, Croats, Bulgarians, and Slovaks). This could be derived from the Gothic word gaits 'goat'. What makes this plausible is that gaita is used for the bagpipe in the distant Spanish province of Galicia, which could be a result of Visigoth migration (Corominas 1992: III: 18).

It is not clear whether Hungarians' ancestors got bagpipes before or shortly after arriving in Hungary. In a grave of the Avar people at Jánoshida in Hungary, dated to the 6th-8th centuries, a skeleton was found clutching a double-pipe of bone, which had been tied together. This may have been part of a bagpipe or bagless hornpipe, 
but other Avar grave finds of blowpipes suggest that the bagpipe was known among them. The arrangement of holes (Figure 3b) resembles the set-up of Mari bagpipes. There are five holes on the melody pipe, and the bottom two line up exactly with the two holes in the adjacent contrabass pipe (Baines 1960: 51-52; Kozák 1997 and 2001; Szabó 2004: 49).

The Avars were horse-riding nomads from Central Asia, who brought East European peoples with them when they settled in Hungary after the collapse of Roman and Hun rule of the area. If Hungarians' ancestors were not in this wave of settlers, they arrived shortly thereafter in an area where double pipes and polyphonic playing were part of the culture. Unequal-hole parallel pipes have a very limited distribution, so there may be a connection between Hungarian and Avar instruments, perhaps even with their history of residence near the Volga Finns and their Turkic neighbors. Kozák (1997) argues that the unusual bagpipes of the Carpathian Basin and the Middle Volga have a common origin, and speculates that the name of an ancient Hungarian group (Sabir) might be related to bagpipe names in the Volga region (süvir [Mari] and sapar [Chuvash]).

The main social base of bagpiping was among male herders of sheep and swine. Besides passing the time during the solitary task of herding, bagpiping could also fend off wolves or other predators. Soldiers and professional musicians (including Gypsy bands) formerly played bagpipes, but turned to the clarinet and other instruments with more stable tuning, variable volume, and suitability for ensemble playing and new composition styles. Pipers traditionally played at weddings, christenings, name-day celebrations, communal work gatherings (e.g., spinning bees, corn huskings, harvesting), pubs, carnivals, dances, processions and plays at Christmas (Manga 1950, 1965, 1969; Szabó, 2004: 38, 40, 55-58.)

The Catholic Church did not show much hostility toward pipers, perhaps because conversion of the Hungarians to Christianity happened so long ago. Shepherds (associated with bagpipes in Hungary) had an important role in nativity reenactments, as the first ones to pay homage to the newborn Jesus (Manga 1969: 42). Their watching over flocks also provided a metaphor for spiritual guidance of believers. Still, there are some vestiges of pagan rites involving bagpipes. For example, a ritual to promote growth of the hemp crop involved a piper and a dancer visiting each home to get the occupants to sing and dance (Szabó 2004: 57). (Recall the Mari rite to promote hemp growth via frivolity and piping). Bagpipers often had the reputation of being able to cast and remove spells, as well as to heal the sick, among people and animals (Manga 1965: 55).

Bagpipes had a preeminent place in Hungarian folk music. Drone sounds were made on other instruments. Special bagpipe dances evolved in the 16th and 17th centuries. Singers of a distinct genre of "bagpipe songs" imitated various stylistic features of bagpipe playing (Manga 1965: 1,94). 
Bagpipes began to decline in popularity in the 18th century, as foreign instruments and music styles became more popular. First aristocrats and later wealthy peasants lost interest in hiring pipers. By the beginning of the 20th century, bagpiping was associated with the weddings of the poor and with begging by itinerant musicians (Manga 1965: 17, 55, 63).

Bagpipe traditions lingered in some rural areas of Hungary and enclaves of Hungarians in neighboring lands, when a folk music revival began among urbanites in the 1970s. The latter could learn from living players and makers rooted in herders' subculture. An important factor was interest in preserving dances linked with piping. Folk dance houses, cultural centers, and the Obúda Music School in Budapest offered new opportunities to learn about traditions. Museum collections and folk music archives provided helpful resources. The Hungarian Bagpipe Orchestra, formed in 1989, popularized the instrument. Among the key figures in the revival movement were Sándor Csoóri Jr., Jószef Kozák, and Ferenc Tobak. They learned from the old masters János Szikora, Imre Seres, Pál Gadanyi, and István Pál. The latter individual had parted with his instrument in the 1970s, but researchers Gergely Agócs and Zoltán Juhász persuaded him to play, record, and teach again (Szabó 2004: 56-59). The population size of Hungary means that there is no shortage of participants in bagpipe camps/courses, customers for bagpipe shops, fans for folk musicians, etc.

\section{Conclusion}

The three Finno-Ugric groups with the most viable and best-documented bagpipe traditions had quite different names, designs, playing styles, and repertoires for their instruments. There is not enough in common to make a strong case for a shared prototype of the instrument, although there are some intriguing similarities (e.g., between the double chanters of the Hungarians and the Volga Finns; between the bladder/stomach bag design of the Baltic Finns and the Volga Finns). The ritual and social functions of piping were quite similar among these widely separated groups. This might be due to the obvious or inherent suitability of a loud instrument with an anthropomorphic or zoomorphic sound (resembling human or animal voices) for entertaining crowds at weddings and other festivities, warding off threats, and communicating with beings in the supernatural realm.

The social base of bagpiping has shifted, from farmers and herders to towndwellers. All three groups came perilously close to losing their bagpipe traditions in the mid-20th century, as new musical tastes spread from other cultures. Old-style person-to-person transmission of bagpipe lore was never totally disrupted, and 
played a critical role in inspiring leaders of the revivals. A new development is the involvement of institutions of education and government in arranging instruction for groups. This supplements the longtime role of museums and archives in preserving instruments, transcriptions, recordings, research findings, and other resources for enthusiasts, which did not exist in olden times. Institutions also provide new venues for performances. Bagpiping and other folk arts like dancing and singing continue to be linked, but stage and broadcast performances before large, relatively passive, and ethnically mixed audiences have become common.

New possibilities for international communication and travel make it likely that more sharing of ideas and experiences will occur between the representatives of the different Finno-Ugric bagpiping traditions, as well as with enthusiasts of folk music

revivals elsewhere. Some modifications of old ways of making, playing, and using instruments are likely to result. The recent and successful bagpipe revivals suggest that in our age of globalization and standardization of so many things, a lively spirit of resistance to homogenization and an interest in retaining, exploring, and adapting traditions have been kindled among musicians and audiences alike.

\section{References}

Agócs, Gergely (ed.). (2001) A duda, a furulya és a kanásztülök: A magyar hangszeres zene folklórja. Budapest: Planétás Kiadó.

Allmo, Per-Ulf. (1990) Säckpipan i Norden (pp. 236-281). Musikmuséets skrifter 18. Stockholm: AllWin.

Arndt, Joh. Gottfr. (1747) Der Liefländischen Chronik I, Halle-Magdeburg. Baines, Anthony. (1960) Bagpipes. Occasional Papers on Technology 9, Pitt Rivers Museum, University of Oxford.

Boyarkin, Nicolai. (1995) Types of Mordvinian Instrumental Folk Music. In Mare Kõiva and Kai Vassiljeva (eds.), Folk Belief Today, Tartu: Institute of the Estonian Language and Estonian Museum of Literature (pp. 30-36).

Corominas, Joan. (1992) Diccionario crítico etimológico castellano e hispánico. Madrid: Editorial Gredos.

Éri, Péter. (2001) Adalékok a duda történeti névanyagának kérdéséhez a XVXVIII. századi szótárirodalom tükrében. In Agócs (2001, pp. 251-265, 521).

Faehlmann, Fr. R. (1848) Addendum to Johann Wolfgang Boecler [Johann Forselius]. Der Einfältigen Ehsten Abergläubische Gebräuche, Weisen und Gewohnheiten. Scriptores rerum Livonicarum II, p. 684. 
Gerasimov, Oleg. (1996) Narodnye muzykal'nye instrumenty mari. Yoshkar-Ola: Tsentr Narodnogo Tvorchestva.

Kiviberg, Ando. (1994) Eesti torupilli langus ja taassünd. Graduation thesis. Viljandi: Viljandi Kultuurikolledzh.

Kozák, József. (1997) Kettétört csontsípszár a Bijelo brdoi avar kori temetöben. Communicationes Archeological Hungariae (pp. 195-202). Reprinted in Agócs (2001, pp. 231-241, 519-520).

Kozák, József. (2001) A duda a Kárpát-medence népeinek hangszeres zenéjében. In Agócs (2001, pp. 373-420, 524-525).

Leisiö, Timo. (2014) Bagpipe and pilli in Estonia and Finland: An Etymological Approach. Working Papers of the Third International Congress of Belarusian Studies [2013]. Retrieved from http://icbs.palityka.org/wp-content/uploads/2014/09/09-12_Leisio.pdf .

Leisiö, Timo and Juha Tainio. (1988) "Pisti pillit säkkihinsä": Ajatuksia säkkipillistä Suomenlahden rantamailla. Tampere, Finland: University of Tampere, Department of Folk Tradition, Articles and Reprints 13.

Manga, János. (1950) Nógrádi dudások. A Néprajzi Múzeum füzetei 12. Budapest. Reprinted in Agócs (2001, pp. 125-150, 515-516).

Manga, János. (1965) Hungarian Bagpipers. Acta Ethnographica Academiae Scientiarum Hungaricae XIV, pp. 1-99. Budapest.

Manga, János. (1969) Hungarian Folk Song and Folk Instruments. Budapest: Corvina Press.

Metsmägi, Iris, Meeli Sedrik, and Sven-Erik Soosaar. (2012) Eesti etümoloogiasõnaraamat. Tallinn: Eesti Keele Sihtasutus.

Nettl, Bruno. (1960) Cheremis Musical Styles. Indiana University Publications: Folklore Series 14, Bloomington.

Nikiforov, Pëtr Nikiforovich. (1959) Mariiskie narodnye muzykal'nye instrumenty. Yoshkar-Ola, Mariiskoe Knizhnoe Izdatel'stvo.

Nyberg, Bo. (1990) Drompip, drummpipa, säckepip: Säckpipan hos estlandssvenskarna. In Per-Ulf Allmo, Säckpipan i Norden (pp. 236-281).

Musikmuséets skrifter 18. Stockholm: AllWin.

Olearius, Adam. (1996 [originally 1656]) Moskoovia ja Pärsia teekonna kohta. Tallinn: Olion.

Priedīte, İrisa. (1988) Tautas mūzikas instrumenti. Latvijas Etnogrāfiskais Brīvdabas Muzejs. Riga: Avots.

Pulst, August. (1973) Torupilli Juss ja teised. Kultuur ja Elu 7, pp. 33-36; 8, pp. 20-25; 9, pp. 24-26.

Russow, Balthasar. (1967 [originally 1584]) Liivimaa provintsi kroonika. Translated by Dagmar and Hermann Stock. Stockholm: Vaba Eesti. 
Rüütel, Ingrid. (1969) Eesti uиema rahvalaulu kujunemine. Tartu:

Kirjandusmuuseum. Ph.D. dissertation.

Sebeok, Thomas Albert and Francis J. Ingemann. (1956) Studies in Cheremis: The Supernatural. Viking Fund Publications in Anthropology 22. Wenner-Gren Foundation for Anthropological Research.

Söderbäck, Per. (1940) Rågöborna. Nordiska Muséets Handlingar 13. Stockholm. Szabó, Zoltán. (2004) A duda: The Bagpipe. Budapest: Museum of Ethnography. Tampere, Herbert. (1975) Eesti rahvapillid ja rahvatantsud. Tallinn: Eesti Raamat. Tampere, Herbert. (1999) Eesti rahvaviiside antoloogia. Tallinn: Eesti Keele Instituut.

Tõnurist, Igor. (1976) The Estonian Bagpipe. The Brussels Museum of Musical Instruments Bulletin, 6:1/2, pp. 47-54.

Tõnurist, Igor. (1977) Torupill Lääne-Ingeris. Etnograafiamuuseumi aastaraamat (pp. 212-219). Tallinn: Valgus.

Tõnurist, Igor. (1996) Pillid ja pillimäng eesti külaelus. Tallinn: Teaduste Akadeemia Kirjastus.

Tõnurist, Igor. (1998) Muusika ja tants. In Ants Viires and Elle Vunder (eds.), Eesti rahvakultuur (pp. 459-483), Tallinn: Eesti Entsüklopeediakirjastus.

Viitso, Tiit-Rein and Valts Ernštreits. (2013) Līvõkiel-ēstikiel-leţkīel sõnarontõz. Tartu and Riga: Līvõ Kultūr Sidām, Tartu University, and Latvian Language Agency. Online dictionary retrieved on September 3, 2013 from http://www.murre.ut.ee/liivi/index.html .

Väisänen, Armas Otto. (1948) Mordwinische Melodien. Suomalais-ugrilaisen Seuran toimituksia 92. Helsinki.

Västrik, Ergo-Hart. (1998) Kombest valmistada kalendritähtpäevadel inimesena riietatud õlgkuju. In Mare Kalda and Mare Kõiva (eds.), Sator 1: artikleid usundi- ja kombeloost (pp. 157-189). Tartu: Eesti Keele Instituut. 
Figures 1-5

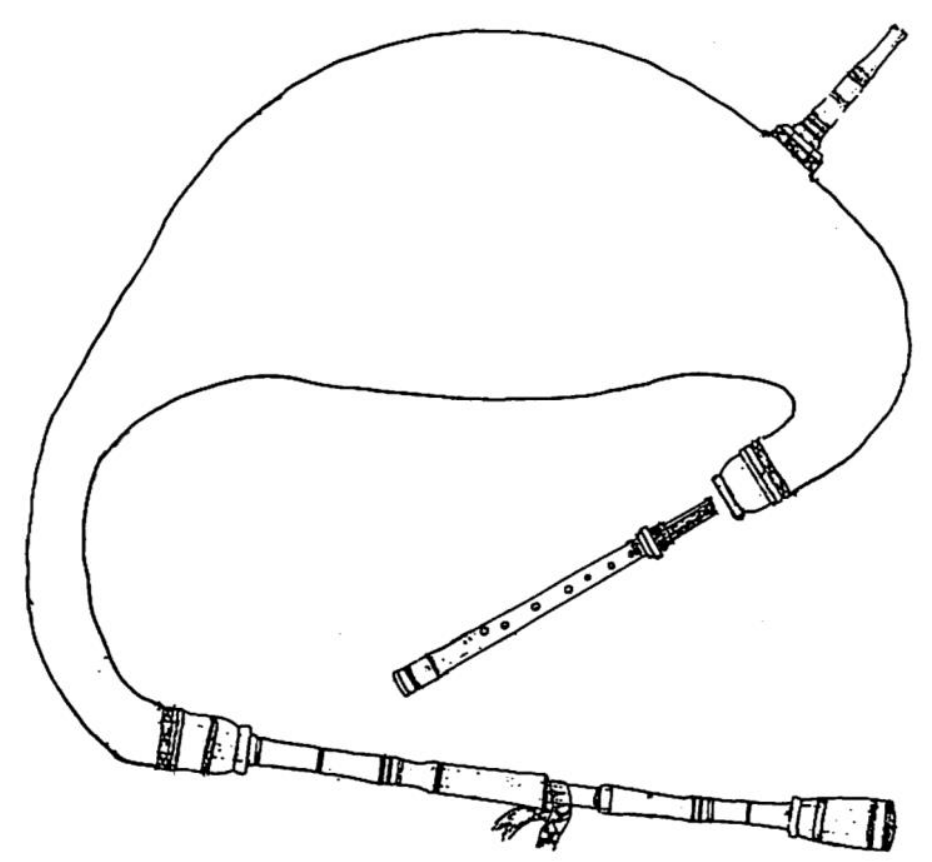

Figure 1. Estonian bagpipe

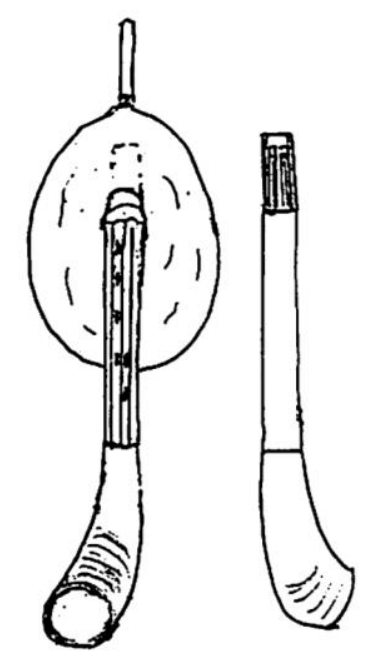

Figure 2. Mari bagpipe

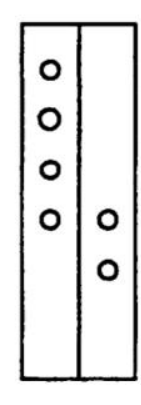

a. Mari

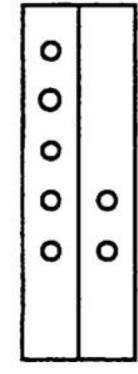

b. Avar

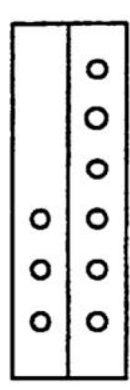

c. Mordvin

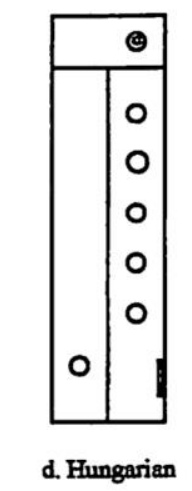

Figure 3. Unequal-Hole Double Chanters

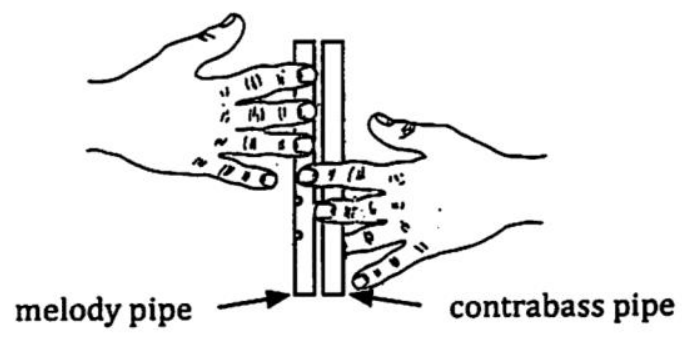

Figure 4

Finger Positions on Mari Bagpipe

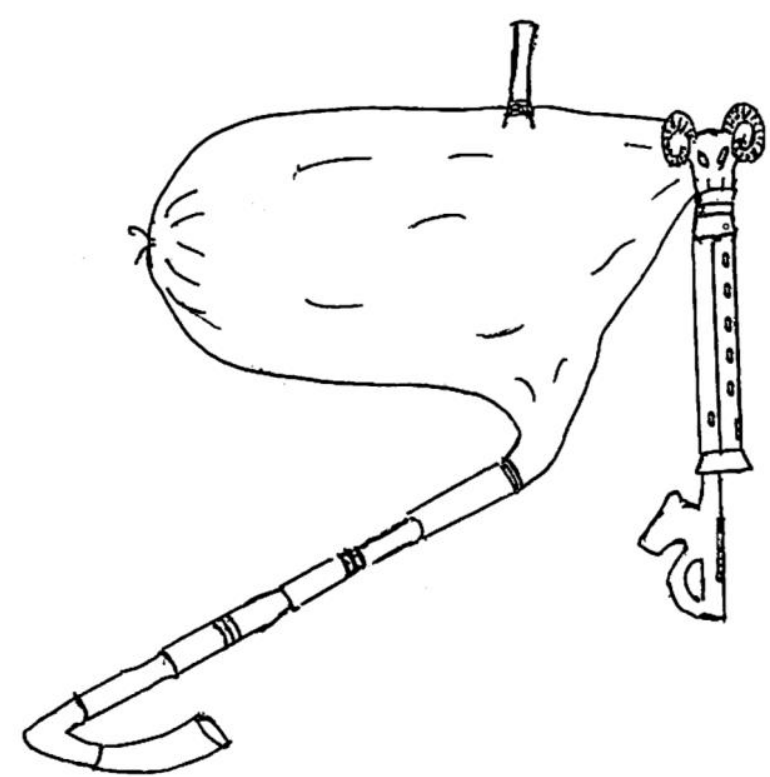

Figure 5. Hungarian bagpipe 